\title{
Age, growth and utility of otolith morphometrics as a predictor of age in the wrasse Coris julis (Labridae) from the eastern Adriatic Sea
}

\author{
FRANE ŠKELJO, JOSIPA FERRI, JURE BRČIĆ, MIRELA PETRIĆ and IVAN JARDAS \\ University of Split, Center of Marine Studies, Livanjska 5/III, 21000 Split, Croatia. E-mail: frane.skeljo@unist.hr
}

\begin{abstract}
SUMMARY: Age and growth of Coris julis were determined by examining sagittal otoliths belonging to fish sampled between November 2008 and October 2009 in the eastern Adriatic Sea (north-central Mediterranean Sea). A total of 1102 specimens (528 males, 487 females and 87 individuals of indeterminate sex), ranging from 48 to $222 \mathrm{~mm}$ total length were analysed. Ninety-two per cent of the otoliths were readable and $68 \%$ of the specimens had two readings in agreement. Counting of daily rings revealed that the second opaque ring represents the first annulus $(315.1 \pm 27.8$ daily rings). The maximum observed age was 7 years for males and 5 years for females, with males dominating in higher age classes $(>3$ years) and females in age classes $1^{+}$and $2^{+}$. Growth was described by the von Bertalanffy growth curves and significant differences were found between males $\left(\mathrm{L}_{\infty}=29.10 \mathrm{~cm}, \mathrm{k}=0.12\right.$ and $\left.\mathrm{t}_{0}=-1.48\right)$ and females $\left(\mathrm{L}_{\infty}=21.27 \mathrm{~cm}, \mathrm{k}=0.21\right.$ and $\mathrm{t}_{0}=-$ 1.08). Otolith mass, length, width and thickness were determined for the otoliths belonging to 465 fish and the utility of these morphometrics as a predictor of age was evaluated. The most precise age estimations were obtained from the otolith length data, followed by the otolith mass.
\end{abstract}

KEY WORDS: age, growth, daily rings, otolith morphometrics, Coris julis, Adriatic Sea.

RESUMEN: EDAD, CRECIMIENTO Y UTILIDAD DE LA MORFOMETRÍA DE LOS OTOLITOS COMO PREDICTOR DE LA EDAD EN EL PEZ CORIS JUlis (LABRIDAE) DEL Adriático oriental. - Se determinó la edad y se estimaron los parámetros de crecimiento de Coris julis basados en el análisis de los otolitos sagita de ejemplares capturados en el Adriático oriental (Norte del Mediterráneo central) entre noviembre de 2008 y octubre de 2009 . Se examinó un total de 1.102 ejemplares (528 machos, 487 hembras, y 87 con sexo indeterminado), con tallas que oscilaron entre 48 y $222 \mathrm{~mm}$ de longitud total. El $92 \%$ de los otolitos analizados resultó legible y las lecturas fueron realizadas por dos lectores concordando en el $68 \%$ de los individuos. El recuento de los incrementos diarios revelaron que el segundo anillo opaco corresponde al primer año $(315,1 \pm 27,8$ incrementos diarios). La edad máxima observada fue de 7 años para los machos y 5 años para las hembras. Los machos eran dominantes en las clases de edad más alta (>3 años) y las hembras en las clases de edad $1^{+}$y $2^{+}$. El crecimiento se determinó mediante el modelo de von Bertalanffy y los parámetros de crecimiento estimados para los machos $\left(\mathrm{L}_{\infty}=29.10 \mathrm{~cm}, \mathrm{k}=0.12\right.$ and $\left.\mathrm{t}_{0}=-1.48\right)$ y las hembras $\left(\mathrm{L}_{\infty}=21.27 \mathrm{~cm}, \mathrm{k}=0.21\right.$ and $\left.\mathrm{t}_{0}=-1.08\right)$ fueron significativamente diferentes. La masa de los otolitos, la longitud, la anchura y el espesor se determinaron para los 465 otolitos y se ha evaluado la utilidad de estas medidas morfometrícas como un predictor de edad. Las estimaciones más precisas de edad se obtuvieron a partir de la longitud de los otolitos, y en segundo lugar por la masa de los otolitos.

Palabras clave: edad, crecimiento, incrementos diarios, morfometría del otolito, Coris julis, mar Adriático.

\section{INTRODUCTION}

The Mediterranean rainbow wrasse, Coris julis (Linnaeus, 1758), is a demersal labrid species found throughout the Mediterranean and along the eastern Atlantic coast from Scandinavia to the Canary Islands (Fischer et al. 1987). It is the most common and abundant wrasse in the Mediterranean, inhabiting seagrass beds as well as rocky and mixed bottoms in the coastal areas, usually from a few metres to $50 \mathrm{~m}$ depth (Quignard and Pras 1986). In the eastern Adriatic it is a common species, being found along the entire coast (Jardas 1996). 
C. julis is a protogynous hermaphroditic species with diandry, i.e. with two types of males: primary males and secondary males, the latter arising from females by sex change. Its sex inversion and gonad organization have been extensively studied for more than five decades (Brusle 1987 and references therein) but we have little other information on the biology of this species, possibly because of its lack of commercial importance.

Although not commercially targeted, $C$. julis is one of the main species in catches from recreational fishing, a growing leisure activity that exerts increasing pressure on fish communities in coastal zones (Morales-Nin et al. 2005, Cardona et al. 2007, Lloret et al. 2008). The impact of fishing on $C$. julis could profoundly affect coastal benthic communities because this species is a major predator of juvenile sea urchins, thereby controlling their abundance and reducing grazing pressure (Guidetti 2004, Hereu et al. 2005 and references therein). This paper investigates age and growth of $C$. julis in order to obtain growth parameters, which are important inputs to stock assessment models and will provide better insight into the life history of this species. This is particularly important because only one article has been published on this subject in the entire Mediterranean, for the Catalan coast area (Gordoa et al. 2000), and it did not provide separate growth parameters for males and females.

In our study fish age was determined by counting annuli in sagittal otoliths, but because this is one of the most laborious and time-consuming ageing methods (Pilling et al. 2003), we also evaluated the use of otolith morphometrics as an alternative. Compared with conventional age determination, methods that use otolith size are objective and have the potential to produce a high number of observations in a short time (Fossen et al. 2003 and references therein). In order to determine the otolith morphometrics that allows for the most reliable and quick prediction of $C$. julis age, we assessed the utility of otolith mass, length, width and thickness by comparing model-estimated and observed ages.

\section{MATERIALS AND METHODS}

\section{Sampling}

Samples of Coris julis were collected monthly from the eastern Adriatic Sea (north-central Mediterranean Sea), between November 2008 and October 2009 (Fig. 1). Fish were caught by hand line, boat seine and lift net in order to sample large, medium and small specimens, respectively. Each fish was measured to the nearest 1 $\mathrm{mm}$ total length $\left(\mathrm{L}_{\mathrm{T}}\right)$ and weighed to the nearest 0.1 gram; sex was determined by macroscopic analysis of the gonads. When gonads were poorly developed, a gonadal tissue smear was examined under a compound microscope to obtain reliable sex determination. From each fish, sagittal otolith pairs were removed, cleaned and stored dry for later examination.

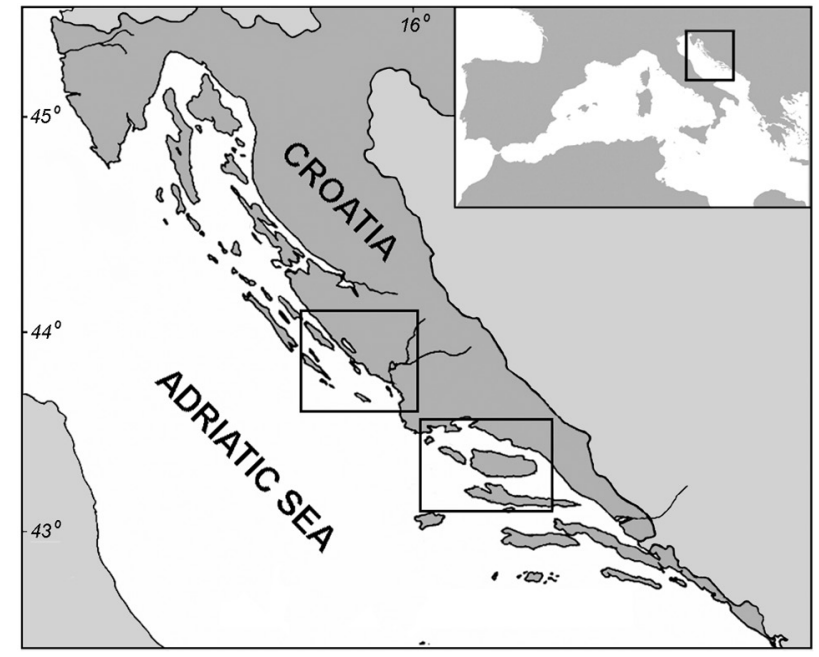

FIG. 1. - Map of the eastern Adriatic Sea (north-central Mediterranean) with indicated sampling areas.

\section{Otolith preparation and reading procedure}

The medial face of a single randomly selected otolith from each pair was polished to the core using wet abrasive paper and photographed under a stereo microscope $(3.75 \times)$ with reflected light against a dark background. Otoliths displayed well-defined alternating opaque and translucent zones. We decided to use images for age reading because their size and quality made it easier to interpret the zoning pattern than the direct observations under the microscope.

A subsample of 20 otolith pairs was selected to determine the first annual ring by examination of daily rings. These otoliths were mounted on slides using Crystalbond ${ }^{\mathrm{TM}}$ adhesive and finely ground using lapping films with different grit grades $(30-5 \mu \mathrm{m})$. Prepared otoliths were photographed under the transmitting light microscope $(100-400 \times)$, revealing a pattern of narrow alternating light and dark zones assumed to represent daily growth rings because in other wrasses they were demonstrated by mark-recapture (Victor, 1982). Daily rings were counted on the single otolith from each pair, starting from the core and proceeding towards the otolith margin. For each of these otoliths we determined the number of daily rings corresponding to each visible annual ring by comparing photographs showing daily and annual growth zones.

Once the first annulus was confirmed by daily counts, the age of each fish was determined from the number of annuli, the assumed hatch-date and the date of capture, without knowledge of the fish length or sex. The spawning period of $C$. julis in the study area lasts from May to September, with a peak in July (author's unpublished data), so the hatch date was assigned to 1 July. The date of capture and hatch date were known to the readers in order to estimate the annual fraction elapsed since the last hatch date, which was added to the number of complete annuli. Annual fraction was included in the age estimate to avoid potential bias due 
to the differences in capture date (Gordoa and Molí 1997). Otoliths with poorly defined annual growth rings were considered unreadable and were discarded. A second reading was carried out two weeks after the first one and only coinciding interpretations were accepted. Relative precision between the two readings was estimated by the index of average percentage error (IAPE) (Beamish and Fournier 1981) and the coefficient of variation (CV) (Chang 1982).

\section{Age and growth estimation}

The periodicity of growth ring formation was validated indirectly by analysing monthly changes in marginal increment ratios (MIR), calculated according to the equation $\mathrm{MIR}=\left(\mathrm{R}_{\mathrm{T}}-\mathrm{R}_{\mathrm{L}}\right)\left(\mathrm{R}_{\mathrm{L}}-\mathrm{R}_{\mathrm{L}-1}\right)^{-1}$, where $\mathrm{R}_{\mathrm{T}}$ is the total radius of the otolith, $\mathrm{R}_{\mathrm{L}}$ is the radius to the last annulus formed and $\mathrm{R}_{\mathrm{L}-1}$ is the radius to the penultimate annulus formed (Araújo and Martins 2007). Required radial measurements were taken along the longest axis of the otolith from the core to the outer edge of each opaque ring and to the otolith margin, using Olympus cell^A imaging software. MIR was calculated for pooled sexes and ages 2-6, and differences between months were tested by one-way ANOVA followed by the post-hoc Tukey test.

Length at age was described by the von Bertalanffy growth model using a non-linear least-square procedure of a Gauss-Newton algorithm. The multivariate Hotelling $\mathrm{T}^{2}$-test was used to compare growth parameters between males and females (Bernard 1981). To back-calculate lengths at age two different models were used: a linear body proportional model according to the equation $\mathrm{L}_{\mathrm{i}}=\left[\left(\mathrm{a}+\mathrm{b} \mathrm{R}_{\mathrm{i}}\right)\left(\mathrm{a}+\mathrm{bR} \mathrm{R}_{\mathrm{T}}\right)^{-1}\right] \mathrm{L}_{\mathrm{T}}($ Francis 1990) and an allometric model according to the equation $\mathrm{L}_{\mathrm{i}}=\left(\mathrm{R}_{\mathrm{i}}\right.$ $\left.\mathrm{R}_{\mathrm{T}}\right)^{\mathrm{c}} \mathrm{L}_{\mathrm{T}}$ (Bagenal and Tesch 1978); $\mathrm{L}_{\mathrm{i}}$ is the back-calculated total length of an individual when the $i$ th annulus was formed, $\mathrm{R}_{\mathrm{i}}$ is the otolith radius to the $i$ th annulus, $\mathrm{R}_{\mathrm{T}}$ is total otolith radius, $\mathrm{L}_{\mathrm{T}}$ is total fish length, $\mathrm{a}$ and $\mathrm{b}$ are parameters of the linear total length-otolith radius regression and $\mathrm{c}$ is the parameter of the allometric total length-otolith radius relationship.

\section{Otolith morphometrics}

A subsample of 465 randomly selected otolith pairs was selected to assess otolith morphometrics. Prior to polishing, whole otoliths were photographed with an Olympus DP-25 digital camera attached to a stereo microscope and otolith length and width were measured to the nearest $0.001 \mathrm{~mm}$ using Olympus cell^^${ }^{\wedge}$ Imaging Software. Otolith length was defined as the longest axis between the anterior and posterior otolith edge and width as a distance from the dorsal to ventral edge taken perpendicular to the length through the otolith focus. Otolith thickness was measured using a digital calliper with a precision of $0.01 \mathrm{~mm}$ and otolith mass was weighed to the nearest $0.1 \mathrm{mg}$. Differences between left and right otoliths were tested by paired $t$

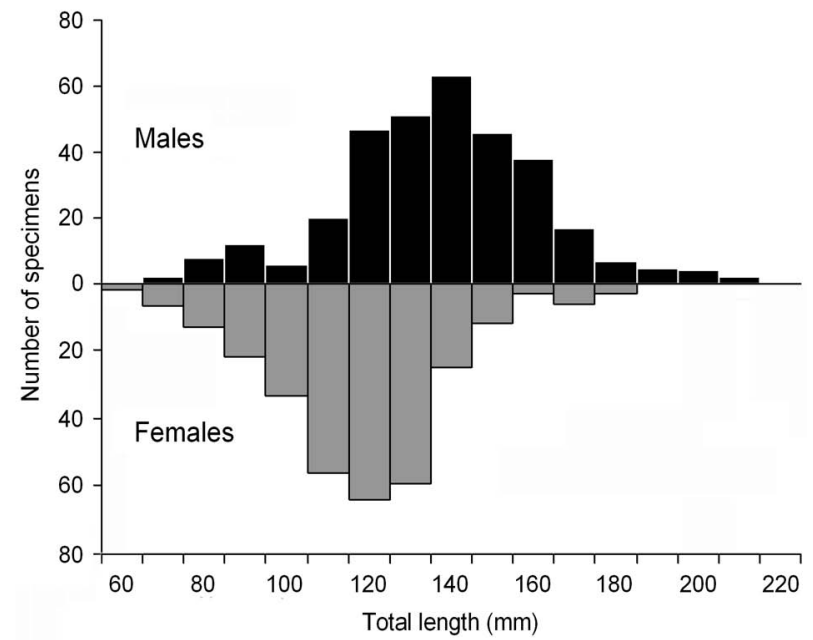

FIG. 2. - Coris julis. Length structures of males and females sampled between November 2008 and October 2009 in the eastern Adriatic Sea.

test and ANCOVA was used to test for differences in otolith measures between the sexes, considering fish length as a covariate.

Once the age was determined by counting annual rings, relationships between observed otolith age and otolith morphometrics (mass, length, width and thickness) were constructed using the power model. Otoliths were randomly divided into $60 \%$ and $40 \%$ subsets and the power function was fitted to the $60 \%$ subset to produce predictive equations, allowing for the estimation of fish age in the remaining $40 \%$ subset. Precision of the predicted ages relative to the observed age estimates was tested by the IAPE and CV indices.

\section{RESULTS}

A total of 1102 specimens of Coris julis were collected for the age analysis: 528 males, 487 females and 87 individuals of indeterminate sex (juveniles and specimens with poorly developed gonads). Male and female total lengths ranged from 73 to $222 \mathrm{~mm}$ and from 60 to $183 \mathrm{~mm}$, respectively. Length frequency distributions were significantly different between sexes (Kolmogorov-Smirnov test; $P<0.001$ ), with females dominating in the $\leq 130 \mathrm{~mm}$ and males in the $\geq 140 \mathrm{~mm}$ length classes (Fig. 2).

\section{Daily ring analysis}

Daily rings were successfully counted for 17 otoliths and their numbers were assigned to the corresponding annual growth rings, ranging from the core to the second opaque ring (Table 1 ). In all the examined otoliths we observed a distinctive opaque core consisting of $35.5 \pm 2.9$ (mean \pm sd) daily rings, a period which closely corresponds with the $C$. julis planktonic larval duration (PLD) (Raventós and Macpherson 2001, Fontes et al, 2010). The PLD zone is followed by the narrow translucent ring $(F)$, deposited during 20.6 \pm 4.6 
TABLE 1. - Coris julis. Mean width (um) and daily ring counts of the annual zones up to the second translucent ring (PLD, planktonic larval duration; $\mathrm{F}$, "false" translucent ring; $\mathrm{O}_{1}$, first opaque ring; $\mathrm{T}_{1}$, first translucent ring; $\mathrm{O}_{2}$, second opaque ring); $\mathrm{N}$ is number of observations.

\begin{tabular}{lccccc}
\hline Annual zone & \multicolumn{2}{c}{$\begin{array}{c}\text { Annual ring } \\
\text { width }(\mu \mathrm{m})\end{array}$} & \multicolumn{2}{c}{$\begin{array}{c}\text { Number of } \\
\text { daily rings }\end{array}$} & $\mathrm{N}$ \\
& Mean & $\mathrm{SD}$ & Mean & $\mathrm{SD}$ & \\
\hline $\mathrm{PLD}$ & 162.1 & 17.8 & 35.5 & 2.9 & 17 \\
$\mathrm{~F}$ & 84.0 & 27.9 & 20.6 & 4.6 & 14 \\
$\mathrm{O}_{1}$ & 178.2 & 36.4 & 59.7 & 18.0 & 13 \\
$\mathrm{~T}_{1}$ & 135.3 & 42.7 & 79.3 & 27.5 & 11 \\
$\mathrm{O}_{2}$ & 240.8 & 47.5 & 123.9 & 18.7 & 5 \\
\hline
\end{tabular}

days (Fig. 3). The next opaque $\left(\mathrm{O}_{1}\right)$ and translucent $\left(\mathrm{T}_{1}\right)$ zone formed in approximately 2 and 3 months each, although their duration varied substantially between different otoliths, as indicated by large standard deviations (see Table 1). Since assumed birthdate is 1 July, $\mathrm{O}_{1}$ roughly corresponded with the period SeptemberOctober, and $\mathrm{T}_{1}$ with the period November-January, which indicated that opaque zones formed during the warmer and translucent zones during the colder period of the year. The second opaque ring $\left(\mathrm{O}_{2}\right)$ was much broader than the first one and its formation took approximately 4 months. Daily ring counts revealed that the second opaque ring roughly corresponds with the first year of life (315.1 \pm 27.8 daily rings) so henceforth fish age was estimated by counting opaque annual rings, starting with the second one (Fig. 3).

\section{Age and growth}

Of the 1102 obtained otoliths, $91(8.3 \%)$ where considered unreadable and discarded; for the remaining $1011(91.7 \%)$ age was successfully determined in two independent readings. Percentage agreement between the readings was relatively high $(68.3 \%)$ with quite low IAPE and CV values $(6.6 \%$ and $9.4 \%$, respectively). The remaining readings differed by one $(28.2 \%)$ or two years $(3.5 \%)$. Only age counts which coincided between two readings were considered reliable, so in further analysis we used age-at-length data

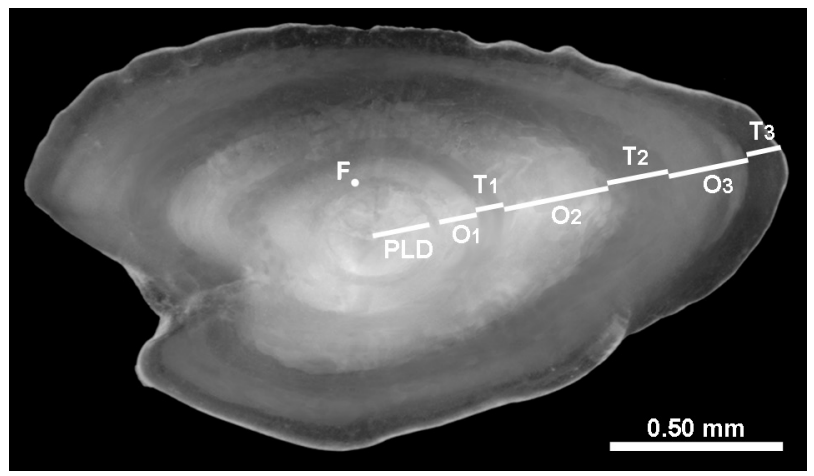

FIG. 3. - Coris julis. Sagittal otolith of a $2^{+}$year old specimen, indicating: planktonic larval duration (PLD), "false" translucent ring $(\mathrm{F})$, three translucent rings $\left(\mathrm{T}_{1}-\mathrm{T}_{3}\right)$ and three opaque rings $\left(\mathrm{O}_{1}-\mathrm{O}_{3}\right)$; second opaque ring $\left(\mathrm{O}_{2}\right)$ corresponds to the first year of age.

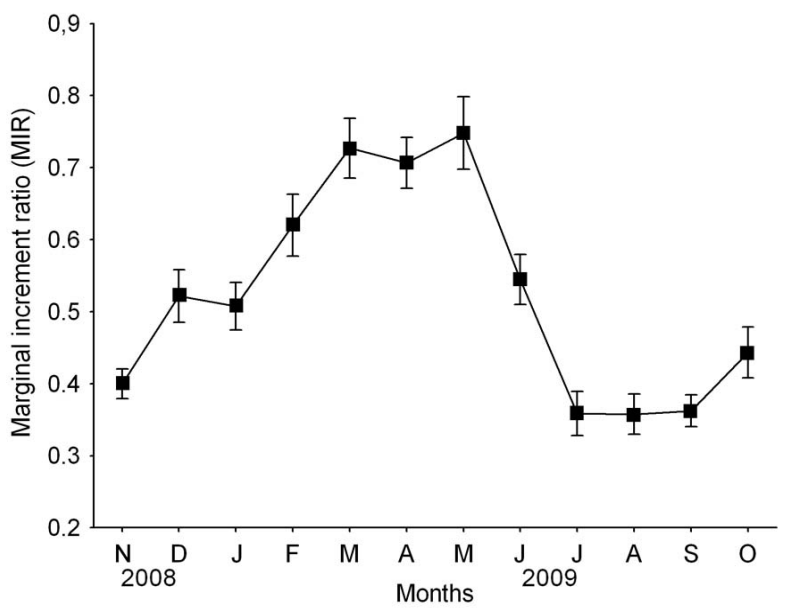

FIG. 4. - Coris julis. Monthly changes in the mean marginal increment ratio (MIR); vertical bars are \pm 1 SE.
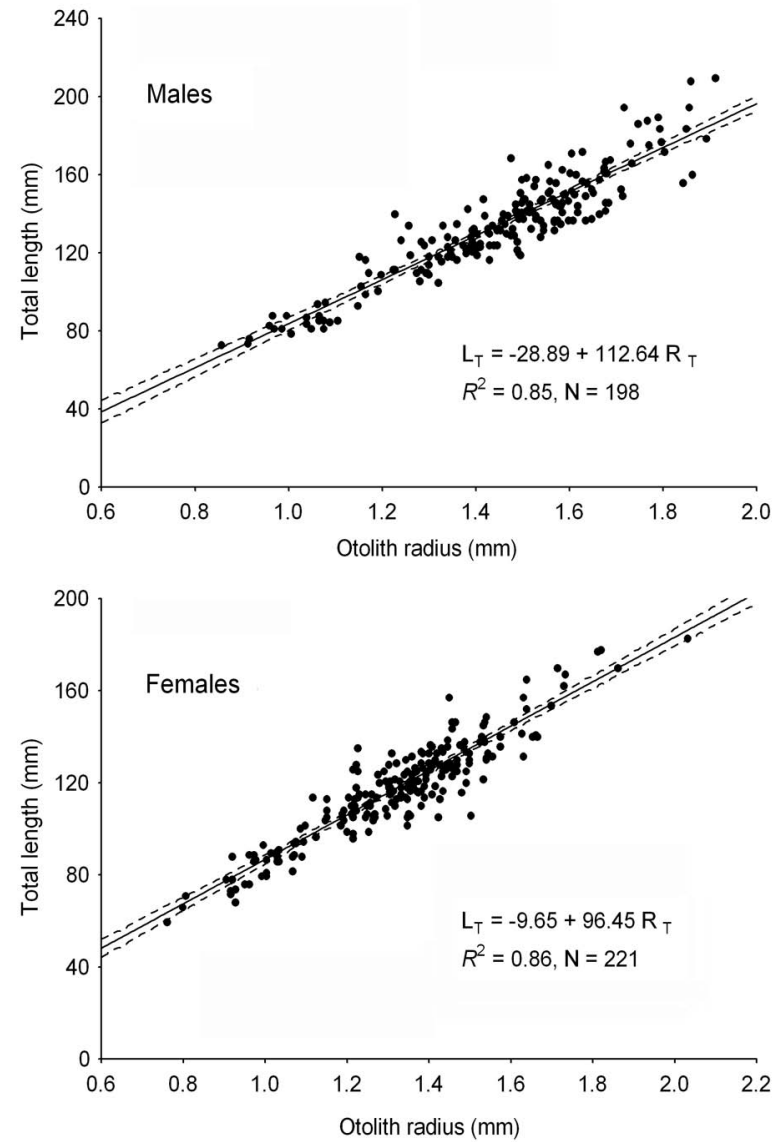

FIG. 5. - Coris julis. Relationship between fish total length and otolith radius for males and females.

for 328 males, 305 females and 58 individuals of indeterminate sex. The maximum observed age was 7 years for males and 5 years for females. Most of the fish, accounting for $81 \%$ of the total sample, were between 2 and 4 years old. In age classes $1^{+}$and $2^{+}$females were dominant, in age class $3^{+}$the sexes were almost equally represented, and in age classes $4^{+}$and $5^{+}$males were dominant. 
TABLE 2. - Coris julis. Mean observed and back-calculated lengths at age for males and females.

\begin{tabular}{|c|c|c|c|c|c|c|c|c|c|}
\hline \multirow[t]{2}{*}{ Age } & \multirow[t]{2}{*}{$\mathrm{N}$} & \multirow[t]{2}{*}{ Observed mean } & \multicolumn{7}{|c|}{ Age group (years) } \\
\hline & & & I & II & III & IV & V & VI & VII \\
\hline \multicolumn{10}{|c|}{ Males } \\
\hline 1 & 16 & 82.5 & 58.3 & & & & & & \\
\hline 2 & 29 & 111.0 & 59.2 & 92.0 & & & & & \\
\hline 3 & 68 & 130.8 & 60.8 & 89.6 & 115.1 & & & & \\
\hline 4 & 61 & 147.9 & 59.4 & 90.2 & 113.7 & 136.2 & & & \\
\hline 5 & 17 & 167.2 & 64.4 & 96.2 & 118.6 & 138.9 & 159.1 & & \\
\hline 6 & 5 & 180.4 & 65.6 & 96.1 & 118.2 & 137.0 & 154.9 & 173.1 & \\
\hline 7 & 2 & 197.0 & 59.8 & 89.6 & 115.1 & 133.1 & 152.8 & 174.6 & 192.8 \\
\hline \multicolumn{3}{|c|}{ Back-calculation (linear model) } & 60.4 & 91.0 & 115.0 & 136.7 & 157.7 & 173.5 & 192.8 \\
\hline \multicolumn{3}{|c|}{ Back-calculation (allometric model) } & 63.9 & 91.8 & 114.9 & 136.3 & 157.2 & 173.1 & 192.6 \\
\hline \multicolumn{10}{|c|}{ Females } \\
\hline 1 & 41 & 85.5 & 65.2 & & & & & & \\
\hline 2 & 76 & 114.4 & 66.5 & 96.1 & & & & & \\
\hline 3 & 67 & 124.0 & 66.2 & 90.8 & 112.8 & & & & \\
\hline 4 & 32 & 144.8 & 67.9 & 97.5 & 117.5 & 136.7 & & & \\
\hline 5 & 5 & 157.2 & 67.2 & 93.0 & 112.7 & 128.7 & 144.5 & & \\
\hline \multicolumn{3}{|c|}{ Back-calculation (linear model) } & 66.4 & 94.3 & 114.2 & 135.6 & 144.5 & & \\
\hline \multicolumn{3}{|c|}{ Back-calculation (allometric model) } & 66.8 & 94.1 & 114.0 & 135.4 & 144.1 & & \\
\hline
\end{tabular}

The mean MIR was lowest in the summer and highest in the late autumn-winter period (Fig. 4). Presence of the single yearly minimum and maximum indicates the formation of one annual ring per year, with an opaque zone laid down during the summer. Differences between months were significant (ANOVA, $P<0.001$ ) and the Tukey test showed that MIR was significantly lower in July-September than in most of the remaining months, thus supporting the conclusion that annulus formation occurs yearly in the summer period.

Fish total length and otolith radius showed a strong linear correlation for both males $\left(R^{2}=0.88\right)$ and females $\left(R^{2}=0.81\right)$ (Fig. 5). Mean back-calculated total lengths were lower than the observed lengths for both models and all age groups, particularly in the lower age classes. Two back-calculation models gave similar results, with the allometric model giving slightly higher fish-size estimations for the first year of age for females and the first two years of age for males, but slightly lower estimations for all other age groups (Table 2). The von Bertalanffy growth parameters were calculated for observed and back-calculated lengths at age, separately for males, females and all specimens combined (Table 3). In all cases, backcalculation resulted in greater estimates of asymptotic length $\left(\mathrm{L}_{\infty}\right)$ and lower estimates of growth coefficient (k). The growth curves for observed lengths at age are shown in Figure 6. The Hotelling $\mathrm{T}^{2}$-test found significant differences between male and female growth parameters regarding observed $\left(T^{2}=2014.59\right.$ $\left.>\mathrm{T}_{0}^{2}{ }_{0.001,3,629}=16.52\right)$ and back-calculated values for both linear and allometric model $\left(\mathrm{T}^{2}=1445.44\right.$ $>\mathrm{T}_{0}^{2}{ }_{0.001,3,415}=16.65$ and $\mathrm{T}^{2}=968.02>\mathrm{T}_{0}^{2}{ }_{0.001,3,415}=$ 16.65 , respectively).

\section{Otolith morphometric-age relationships}

Otolith mass, length, width and thickness were measured on the otoliths belonging to 465 fishes ranging between 55 and $210 \mathrm{~mm} \mathrm{~L}_{\mathrm{T}}$. No significant differences in morphometric measures were found between left and right otoliths (paired $t$ test, $P>0.05$ for all measures) and between males and females (ANCOVA; $P>0.05$ for all measures), so data were pooled for both

TABLE 3. - Coris julis. Von Bertalanffy growth parameters for males, females and all specimens estimated by otolith reading and

\begin{tabular}{|c|c|c|c|c|c|c|c|c|}
\hline & $\mathrm{L}_{\infty}(\mathrm{cm})$ & se & $\mathrm{k}\left(\mathrm{y}^{-1}\right)$ & se & $t_{o}(y)$ & se & $R^{2}$ & $\mathrm{~N}$ \\
\hline \multicolumn{9}{|l|}{ Otolith readings } \\
\hline Males & 29.10 & 3.90 & 0.12 & 0.03 & -1.48 & 0.33 & 0.83 & 328 \\
\hline Females & 21.27 & 2.12 & 0.21 & 0.05 & -1.08 & 0.26 & 0.81 & 305 \\
\hline All specimens & 25.24 & 1.46 & 0.16 & 0.02 & -1.17 & 0.13 & 0.88 & 691 \\
\hline \multicolumn{9}{|c|}{ Back-calculation (linear model) } \\
\hline Males & 36.60 & 10.96 & 0.09 & 0.04 & -0.68 & 0.32 & 0.81 & 198 \\
\hline Females & 23.30 & 4.37 & 0.17 & 0.06 & -0.62 & 0.27 & 0.78 & 221 \\
\hline All specimens & 34.00 & 6.46 & 0.10 & 0.03 & -0.85 & 0.19 & 0.83 & 454 \\
\hline \multicolumn{9}{|c|}{ Back-calculation (allometric model) } \\
\hline Males & 40.69 & 15.32 & 0.08 & 0.04 & -0.90 & 0.37 & 0.81 & 198 \\
\hline Females & 23.51 & 4.57 & 0.17 & 0.06 & -0.66 & 0.28 & 0.78 & 221 \\
\hline All specimens & 35.78 & 7.63 & 0.09 & 0.03 & -0.99 & 0.20 & 0.83 & 454 \\
\hline
\end{tabular}




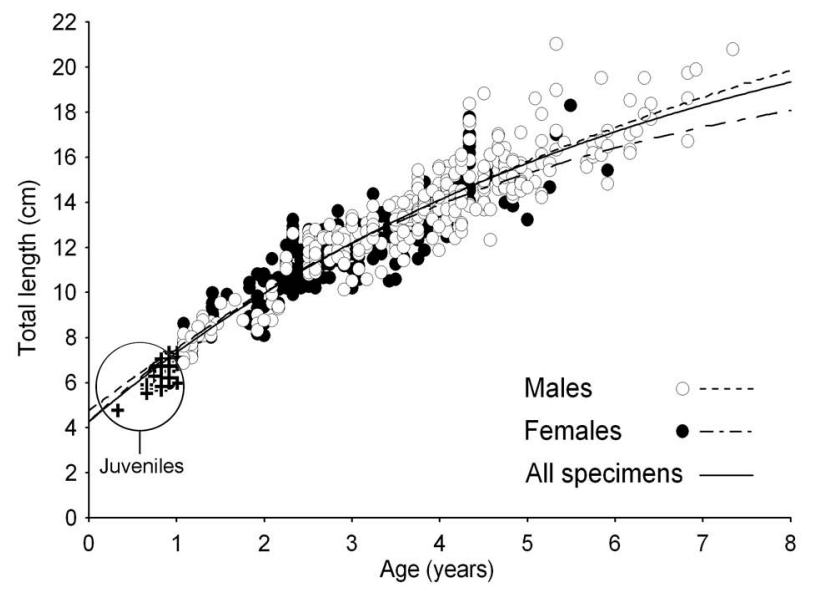

FIG. 6. - Coris julis. Observed length-at-age data fitted with von Bertalanffy growth curves for males, females and all specimens.
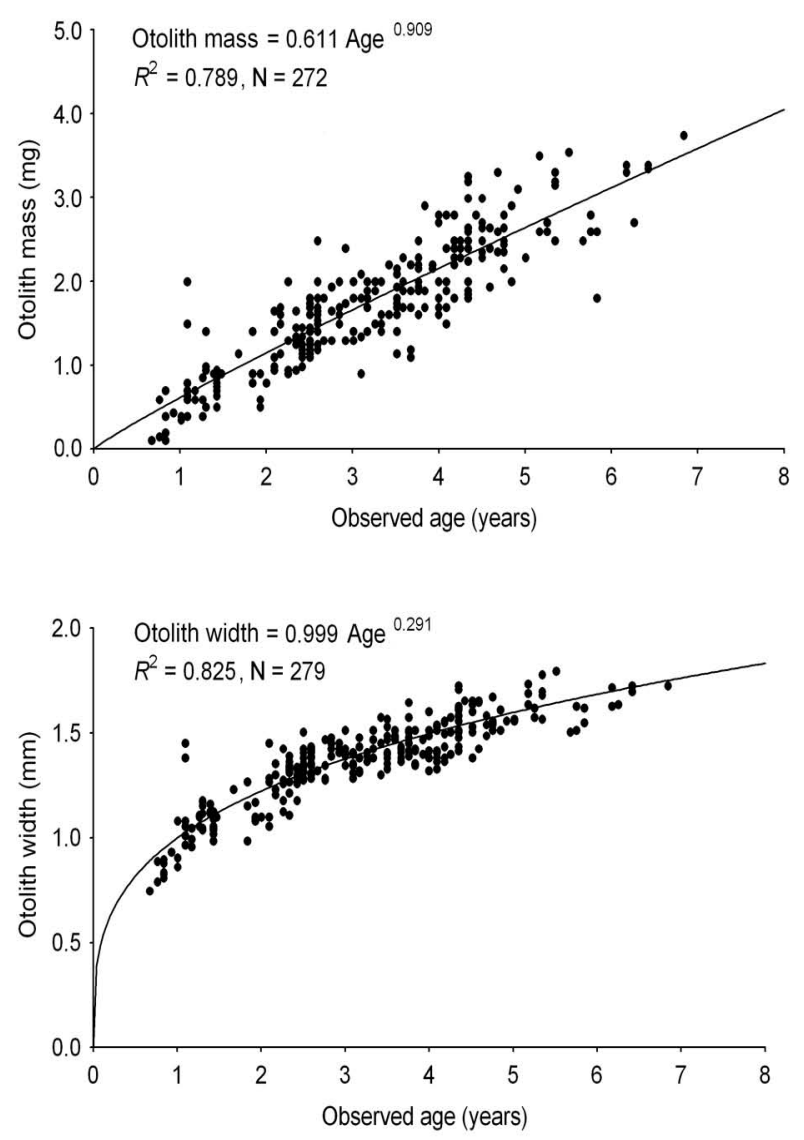

sexes and mean values for each otolith pair were used in further analysis.

Relationships between otolith morphometrics and observed age for the subsample of 279 otoliths are presented in Figure 7. A power model explained between $69.7 \%$ and $83.4 \%$ of the variation in age. Based on the equations provided in Figure 7, the age of the remaining 186 otoliths was estimated from the otolith morphometrics, plotted against corresponding observed ages, and the relationships were described by simple linear regression (Table 4, Fig. 8). All regressions were significant $(P<0.05)$, accounting for $64.0-85.0 \%$ of the variation in estimated age. The intercept of all four linear regressions was slightly underestimated (lower then 0) and the slope slightly overestimated (higher then 1). However, 95\% confidence intervals included intercept $=0$ and slope $=1$ for all equations except when otolith width was used as an age estimator. Most
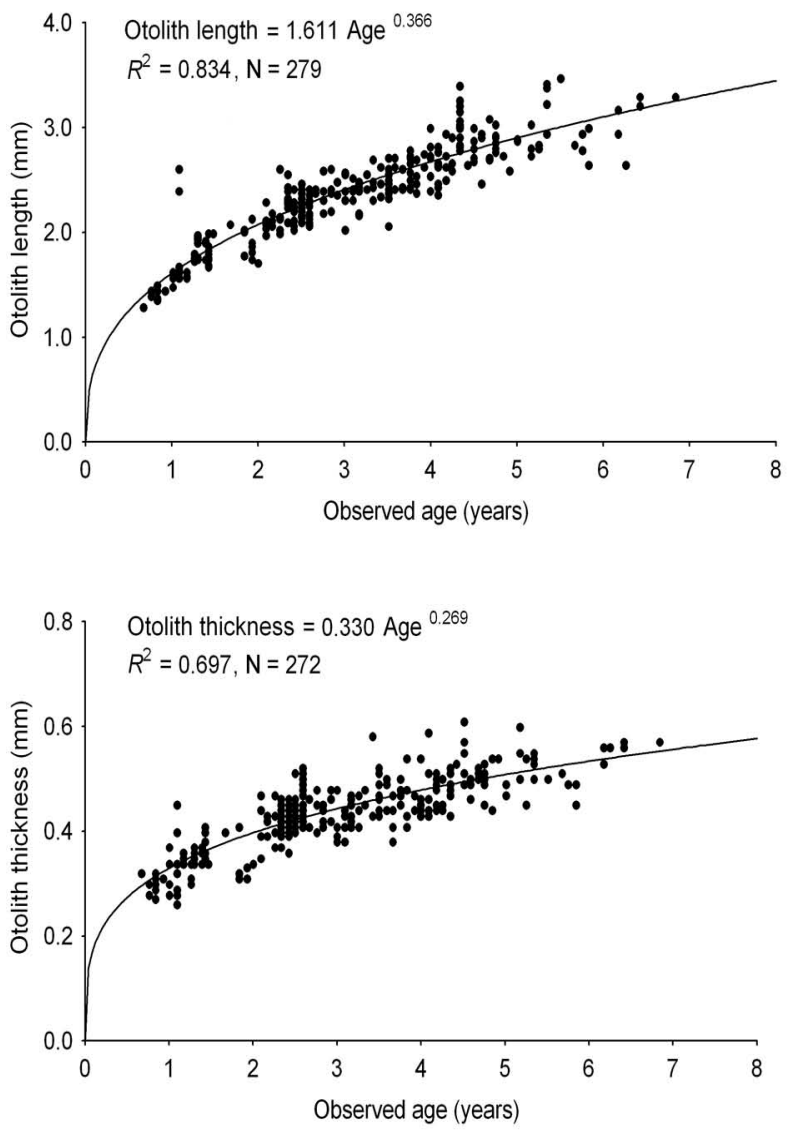

FIG. 7. - Coris julis. Relationships between otolith morphometrics and observed fish age.

TABLE 4. - Coris julis. Simple linear regression equations for the relationship between observed age (independent variable) and estimated age (dependent variable).

\begin{tabular}{lcccc}
\hline Age estimation predictor & Intercept (95\% IC) & Slope (95\% IC) & $R^{2}$ & $\mathrm{~N}$ \\
\hline Otolith mass & $-0.125(-0.359,0.108)$ & $1.067(0.997,1.137)$ & 0.84 & 186 \\
Otolith length & $-0.018(-0.236,0.201)$ & $1.040(0.975,1.106)$ & 0.85 & 186 \\
Otolith width & $-0.192(-0.465,0.082)$ & $1.117(1.035,1.199)$ & 0.80 & 186 \\
Otolith thickness & $-0.001(-0.415,0.412)$ & $1.103(0.979,1.227)$ & 0.64 & 186 \\
\hline
\end{tabular}



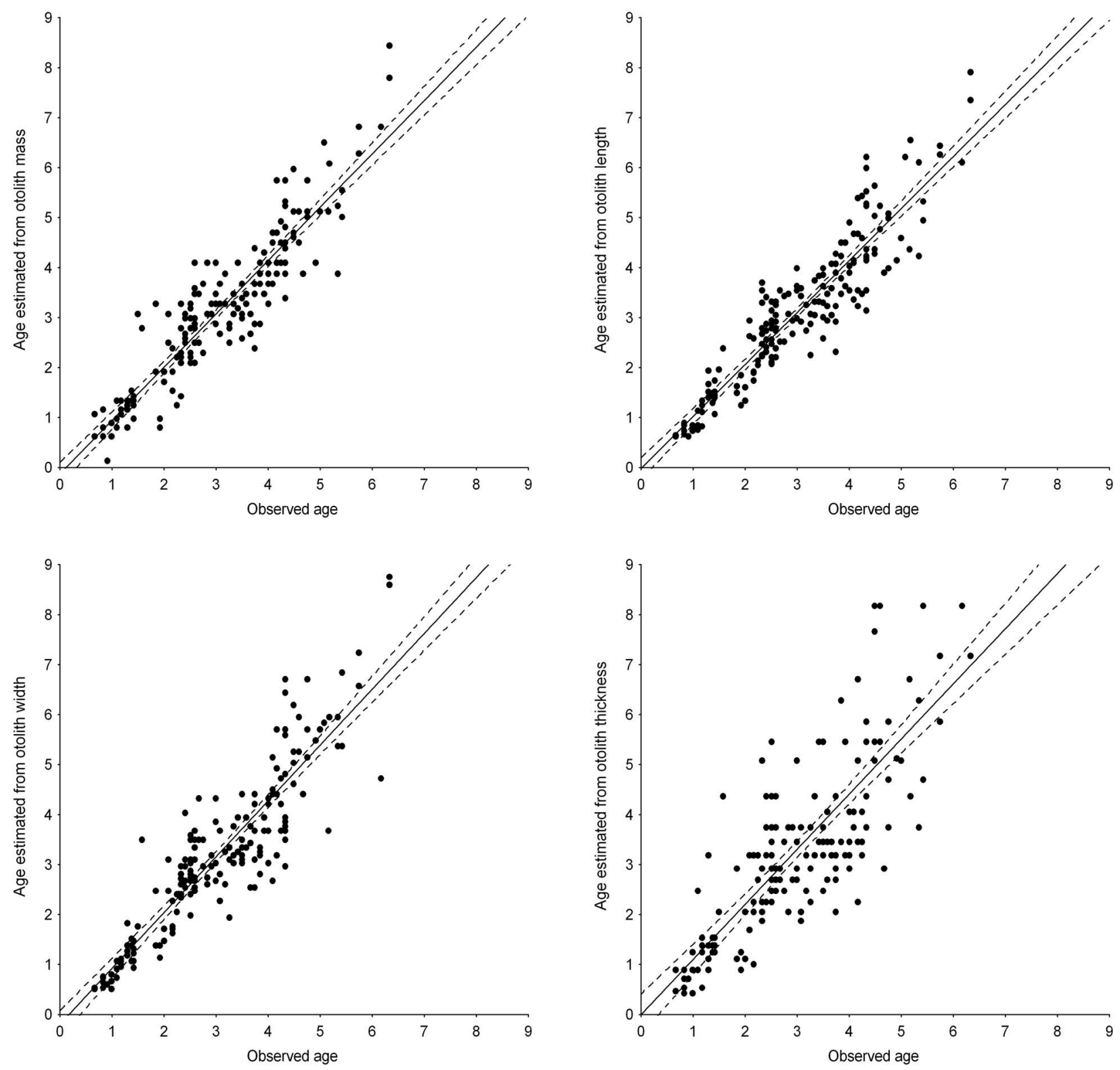

FIG. 8. - Coris julis. Comparison of the observed age and age estimated from otolith mass, length, width and thickness.

precise age estimations were obtained from the otolith length data (IAPE $=7.4 \% ; \mathrm{CV}=9.6 \%$ ), followed by the otolith mass $(8.6 \% ; 10.1 \%)$, width $(9.2 \% ; 11.6 \%)$ and thickness $(12.7 \% ; 16.0 \%)$.

\section{DISCUSSION}

The use of sagittal otoliths for Coris julis age determination proved reasonably straightforward, although time-consuming due to the necessity for otolith preparation prior to age reading. We decided to label the first visible translucent ring as "false" since it was too narrow compared with the subsequent rings to represent a significant period of time, but it was nevertheless consistently found in different otoliths. It was formed in approximately 3 weeks during the summer months, as calculated from the birthdate and PLD, which is surprising since all succeeding translucent rings were associated with the winter period. However, not all factors affecting otolith deposition are strictly environmental (Radtke and Shafer 1992) and this translucent ring could be interpreted as a transitional zone which indicates a developmental transformation from a pelagic larval phase to a benthic phase at the time of settlement.

Once we determined that the second opaque ring represents the first annulus, age reading proved both reliable and precise, as indicated by the low IAPE and $\mathrm{CV}$ values and a high agreement between the two readings. The von Bertalanffy model provided a good fit to the growth data for males, females and pooled speci- 
mens, as shown by the determination coefficients for each curve. In the study area $C$. julis grows relatively fast during the first few years of life, attaining 50\% of its maximum observed length during the second year of life. The calculated male asymptotic length agrees well with the maximum observed $C$. julis length (Schneider 1990). Sex reversal from female to male occurred between the third and fifth year of life and, although sexreversed males had a slightly greater mean size than females of the same age, this cannot be considered as evidence of an intersexual difference in growth rates because males and females are the same specimens at different stages of sexual succession (Pajuelo et al. 2002) and it is possible that the largest females in each age group are the first to revert.

Mean back-calculated lengths were lower than the observed lengths for all age groups and both sexes, but differences were more pronounced in the lower age classes and gradually decreased at higher ages. One possible explanation is that back-calculated lengths are biased due to Lee's phenomenon, in which case bias increases as back-calculations proceed farther back in time (Gutreuter 1987). Fitting the von Bertalanffy growth curve to back-calculated data resulted in higher estimates of asymptotic length and lower estimates of the growth coefficient when compared with parameters obtained from the observed lengths at age. This could be explained by the exclusion of all specimens less than one year old from the back-calculation procedure, since they could not be used in a marginal increment analysis. Taking this into account, together with the lower proportion of the growth pattern explained by the back-calculated curves, we assume that the otolith reading provided more reliable growth estimates.

When comparing two back-calculation models we found that the allometric model produced slightly better estimations of length only in the first or second year of age and the linear model at all later ages. Moreover, fitting the von Bertalanffy growth curve to data from the linear model resulted in lower and more realistic estimates of asymptotic length, when compared with maximum reported length of this species. Although the two models produced very similar results, overall we consider the linear model to be more useful for backcalculating $C$. julis length at age and von Bertalanffy growth parameters.

Since growth parameters obtained in this study represent the first separate estimations of male and female $C$. julis growth, it was not possible to compare them with other findings. The only available growth data on this species are provided for both sexes combined (Gordoa et al. 2000), and observed growth parameters for pooled specimens in our study were similar to those obtained by previously mentioned authors $\left(\mathrm{L}_{\infty}=27.15\right.$ $\mathrm{cm} ; \mathrm{k}=0.11$ ) on the Catalan coast (northwestern Mediterranean).

Interpreting annual growth rings in otoliths, as done in our study, is possibly the most accurate technique for estimating individual fish age, but many authors have pointed to its drawbacks-it is labour intensive, time consuming, expensive and dependent on readers' experience (Boehlert and Yoklavich 1998, Cardinale et al. 2000, Pilling et al. 2003, Pino et al. 2004, Ross et al. 2005, Steward et al. 2009). Several studies have demonstrated that otolith size can be used as a proxy for otolith ring counts in ageing fish, although some otolith dimensions may be more useful than others (Steward et al. 2009 and references therein). In our study the average otolith mass, length, width and thickness increased with age throughout the observed range, implying that they may provide a satisfactory method of ageing. A power model described the relationship between otolith morphometrics and age slightly better than the linear regression method, probably because of the specific otolith growth rates of younger fish. As can be seen in Figure 7, otolith length, width and thickness of the $\leq 1$ year old specimens were somewhat lower than we would expect if the growth rate was constant, as assumed in the linear regression. In contrast, relationship between otolith mass and age showed only a marginal departure from linearity, suggesting that the otolith mass increases more or less constantly throughout the life of this species. A linear relationship between otolith weight and observed age has been found for many species, emphasizing the importance of otolith weight as an age predictor (Pino et al. 2004 and references therein). In order to examine the utility of otolith morphometrics for age estimation, it is necessary to compare estimated ages with the known observed ages. With the exception of otolith thickness, all models provided very precise estimates, and choosing which one to use is more of a practical issue. If a stereomicroscope with digital camera and imaging software are available, measuring otolith length may be the best choice because it is a rapid procedure and allows for slightly better precision than the otolith width. On the other hand, weighing otoliths requires only a precise laboratory scale and the model has the additional advantage of relatively constant otolith mass growth rate with age, which could be useful if sample size range is limited.

Although all proposed models contain ageing errors, they may still produce a better estimation of age structure than counting otolith annuli. Worthington et al. (1995) argued that, for ageing large samples, the lower costs of these models can outweigh any advantages of more precise ageing methods applied to smaller samples, while Cardinale et al. (2000) suggested that a technique with a constant error, such as a morphometric model, may be better for evaluating population structure over time than a technique with variable error owing, for example, to changes in otolith readers. In our case, measuring and weighing otoliths required considerably less time than polishing and counting annual rings, while producing very similar age estimates. Although this method requires recalibration when used for a new stock or population because of potential variation in the otolith growth rate with age, we consider 
that once calibrated it allows for quick, inexpensive and precise estimation of $C$. julis age structure.

\section{REFERENCES}

Araújo J.N., Martins A.S. 2007. Age, growth and mortality of white grunt (Haemulon plumieri) from the central coast of Brazil. Sci. Mar. 71(4): 793-800.

Bagenal T.B., Tesch F.W. 1978. Age and growth. In: Bagenal T.B. (ed.), Methods for assessment of fish production in fresh waters. Oxford Blackwell Scientific Publications, pp. 101-136.

Beamish R.J., Fournier D.A. 1981. A method for comparing the precision of a set of age determinations. Can. J. Fish. Aquat. Sci. 38: 982-983.

Bernard D.R. 1981. Multivariate analysis as a means of comparing growth in fish. Can. J. Fish. Aquat. Sci. 38: 233-236.

Boehlert G.W., Yoklavich M.M. 1998. Variability in age estimates in Sebastes as a function of methodology, different readers and different laboratories. Calif. Fish. Game. 70: 210-224.

Brusle S. 1987. Sex-inversion of the hermaphroditic, protogynous teleost Coris julis L. (Labridae). J. Fish. Biol. 30: 605-616.

Cardinale M., Arrhenius F., Johnsson B. 2000. Potential use of otolith weight for the determination of age structure of Baltic cod (Gadus morhua) and plaice (Pleuronectes platessa). Fish. Res. 45: $239-252$

Cardona L., López D., Sales M., Caralt S., Díez I. 2007. Effects of recreational fishing on three fish species from the Posidonia oceanica meadows off Minorca (Balearic archipelago, western Mediterranean). Sci. Mar. 71(4): 811-820.

Chang W.Y.B. 1982. A statistical method for evaluating the reproducibility of age determination. Can. J. Fish. Aquat. Sci. 39: 1208-1210.

Fischer W., Bauchot M.L., Schneider M. 1987. Fiches FAO d'identification des espèces pour les besoins de la pêche. Méditerranée et mer Noire. FAO, Rome, 1529 pp.

Fontes J., Afonso P., Santos R., Caselle J.E. 2010. Temporal variability of larval growth, size, stage duration and recruitment of a wrasse, Coris julis (Pisces: Labridae), from the Azores. Sci. Mar. 74(4): 721-729.

Fossen I., Albert O.T., Nilssen E.M. 2003. Improving the precision of ageing assessments for long rough dab by using digitised pictures and otolith measurements. Fish. Res. 60: 53-64.

Francis R.I.C.C. 1990. Back-calculation of fish length: a critical review. J. Fish. Biol. 36(6): 883-902

Gordoa A., Molí B. 1997. Age and growth of the sparids Diplodus vulgaris, $D$. sargus and D. annularis in adult populations and the differences in their juvenile growth patterns in the northwestern Mediterranean Sea. Fish. Res. 33: 123-129.

Gordoa A., Molí B., Raventós N. 2000. Growth performance of four wrasse species on the north-western Mediterranean coast. Fish. Res. 45: 43-50.

Guidetti P. 2004. Consumers of sea urchins, Paracentrotus lividus and Arbacia lixula, in shallow Mediterranean rocky reefs. Helgol. Mar. Res. 58: 110-116.
Gutreuter S. 1987. Considerations for estimation and interpretation of annual growth rates. In: Summerfelt R., Hall G.H. (eds.), The Age and Growth of Fish. The Iowa State University Press, Ames, pp. 209-242.

Hereu B., Zabala M., Linares C., Sala E. 2005. The effects of predator abundance and habitat structural complexity on survival of juvenile sea urchins. Mar. Biol. 146: 293-299.

Jardas I. 1996. Jadranska ihtiofauna. Školska knjiga, Zagreb, 533 pp.

Lloret J., Zaragoza N., Caballero D., Riera V. 2008. Biological and socioeconomic implications of recreational boat fishing for the management of fishery resources in the marine reserve of Cap de Creus (NW Mediterranean). Fish. Res. 91: 252-259.

Morales-Nin B., Moranta J., García C., Tugores M.P., Grau A.M., Riera F., Cerdà M. 2005. The recreational fishery off Majorca Island (western Mediterranean): some implications for coastal resource management. ICES J. Mar. Sci. 62: 727-739.

Pajuelo J.G., Lorenzo J.M., Méndez M., Coca J., Ramos A.G. 2002. Determination of age and growth of the striped seabream Lithognathus mormyrus (Sparidae) in the Canarian archipelago by otolith readings and backcalculation. Sci. Mar. 66(1): 27-32.

Pilling G.M., Grandcourt E.M., Kirkwood G.P. 2003 The utility of otolith weight as a predictor of age in the emperor Lethrinus mahsena and other tropical fish species. Fish. Res. 60: 493-506.

Pino A.C., Cubillos L.A., Araya M., Sepúlveda A. 2004. Otolith weight as an estimator of age in the Patagonian grenadier, Macruronus magellanicus, in central-south Chile. Fish. Res. 66: $145-156$

Radtke R.L., Shafer D.J. 1992. Environmental sensitivity of fish otolith microchemistry. Aust. J. Mar. Freshw. Res. 43: 935-951.

Raventós N., Macpherson E. 2001. Planktonic larval duration and settlement marks on the otoliths of Mediterranean littoral fishes. Mar. Biol. 138: 1115-1120.

Ross J.R., Crosby J.D., Kosa J.T. 2005. Accuracy and precision of age estimation of Crappies. North. Am. J. Fish. Manage. 25: 423-428.

Quignard J.P., Pras A. 1986. Labridae. In: Whitehead P.J.P., Bauchot M.L., Hureau J.C., Nielsen J., Tortonese E. (eds.), Fishes of the north-eastern Atlantic and the Mediterranean. UNESCO, Paris, pp. 919-942.

Schneider W. 1990. FAO species identification sheets for fishery purposes. Field guide to the commercial marine resources of the Gulf of Guinea. FAO, Rome, $268 \mathrm{pp}$.

Steward C.A., DeMaria K.D., Shenker J.M. 2009. Using otolith morphometrics to quickly and inexpensively predict age in the gray angelfish (Pomacanthus arcuatus). Fish. Res. 99: 123-129.

Victor B.C. 1982. Daily otolith increments in two coral-reef wrasses, Thalassoma bifasciatum and Halichoeres bivittatus. Mar. Biol. 71: 203-208.

Worthington D.G., Fowler A.J., Doherty P.J. 1995. Determining the most efficient method of age determination for estimating the age structure of a fish population. Can. J. Fish. Aquat. Sci. 52: 2320-2326.

Scient. ed.: I. Palomera.

Received October 14, 2011. Accepted January 10, 2012.

Published online May 7, 2012. 